\title{
Apocrine Carcinoma
}

National Cancer Institute

\section{Source}

National Cancer Institute. Apocrine Carcinoma. NCI Thesaurus. Code C4169.

A carcinoma with apocrine differentiation arising from the sweat glands. It presents as single or multiple nodular lesions which may be ulcerated or hemorrhagic and is usually in the axilla and less often in the anogenital region. It grows in the dermis and infiltrates subcutaneous tissues. It is characterized by the presence of large cells with abundant eosinophilic cytoplasm and large often vesicular nuclei. Most cases are slow growing tumors and have a prolonged course. 